
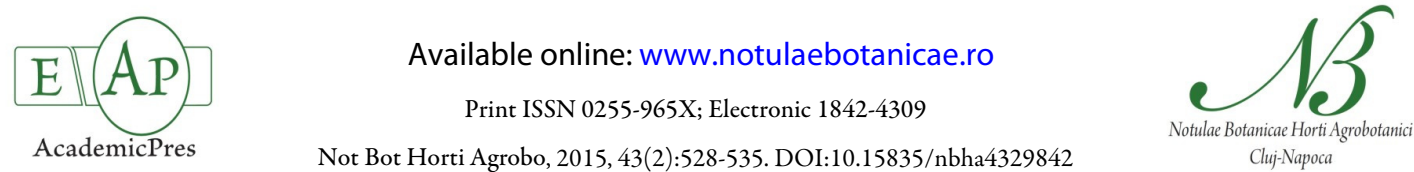

\title{
Patterns of Genetic Diversity and Structure at Fine Scale of an Endangered Moroccan Endemic Tree (Argania spinosa L. Skeels) Based on ISSR Polymorphism
}

\author{
Jamila MOUHADDAB ${ }^{1 *}$, Naima AIT AABD ${ }^{1}$, Hafid ACHTAK ${ }^{2}$, Fouad MSANDA ${ }^{1}$, \\ Abdelaziz ZAHIDI ${ }^{1}$, Abdelkarim FILALI-MALTOUF ${ }^{3}$, Abderrahim FERRADOUSS ${ }^{4}$, \\ Cherkaoui EL MODAFAR ${ }^{5}$, Mohamed NEJMEDDINE ${ }^{1}$, Abdelhamid EL MOUSADIK ${ }^{1}$ \\ ${ }^{1} I b n$ Zohr University, Faculty of Science, Laboratory of Biotechnology and Valorization of Natural Resources, Department of Biology, CP 8106, Agadir 80000, Morocco; \\ j.mouhaddab@gmail.com (*correspondingauthor);aitaabdnaima@gmail.com;fmsanda66@yahoo.fr; \\ dr.abdelazizzabidi@gmail.com;m.nejmeddine@uiz.ac.ma; a.elmousadik@uiz.ac.ma \\ ${ }^{2}$ Cadi Ayyad University, Multidisciplinary Faculty of Safi, Department of Biology, Environment and Health Team, Sidi Bouzid District, P.O. Box 4162, \\ 46000,Safi,Morocco; achtak@gmail.com \\ ${ }^{3}$ MohamedVUniversity FSR Rabat, Morocco; filalimaltouf@gmail.com \\ ${ }^{4}$ National CenterforForestry Research,Marrakech,Morocco;ferabder@yahoo.fr \\ ${ }^{5}$ Cadi Ayyad University, Faculty of Sciences and Technologies, Marrakech, Morocco; elmodafar@fstg-marrakech.ac.ma
}

\begin{abstract}
The preservation of the diversity of endangered populations of argan trees, in their natural habitat, is a crucial step toward their conservation. The aim of the present study was to evaluate the genetic diversity of the argan trees in the wild, and to establish a phylogenetic map using DNA fingerprints. The ultimate goal was to develop a core set that would represent the existing diversity in the whole germplasm. In regard to this, 200 samples of Argania spinosa individual trees were collected from 10 different provenances in the region of Essaouira (Morocco). The genetic variation between and within these argan trees was investigated using previously described Inter-Simple Sequence Repeat markers. These markers generated a total of 149 fragments, in which 148 (99.33\%) were polymorphic. The samples collected in the 'Ouled Lhaj' provenance showed the lowest diversity (\% of polymorphic locus $P=48.32 \%$; genetic diversity Nei $b=0.153$; allelic richness $A=1.483$ ), compared to those collected in the 'Mramer' provenance $(\% P=68.46 \% ; b=0.233 ; A=1.685)$. Also, the results showed a high level of genetic differentiation among provenances (AMOVA $=44 \%, G s t=0.40)$, and a limited gene flow $(N m=0.73)$ between the provenances. In addition, these data suggested a low correlation between the genetic diversity of the tree and their respective geographical location in relation to the proximity to the littoral. Finally, a core collection of 13 genotypes that represent the essential of the detected diversity was established. The distribution pattern of this genetic diversity provides an important baseline data for the conservation strategies of argan tree species in the wild.
\end{abstract}

Keywords: argan tree, genetic diversity, ISSR, core collection, conservation

\section{Introduction}

The argan tree (Argania spinosa L. Skeels) is an endemic forest species in Morocco (Northern West of Africa), covering approximately 828000 hectares (Mhirit et al., 1998). This species belongs to Sapotaceae family and it is a diploid species $(2 n=24)$ (Majourhat et al., 2007), monoecious and allogamous (Msanda et al., 2005) which is believed to be pollinated by insects (El Mousadik and Petit, 1996a). Argania spinosa is a multi-purpose tree (oil-agriculture-forestry-pastoral) with a great genetic diversity (El Mousadik and Petit, 1996a; 1996b). Due to its diversity, the argan tree has a remarkable resilience to withstand climate change adverse, especially in geographical area with increasingly accentuated dryness. In Morocco, the argan tree plays an important role in preserving the local environment, and ensuring the socio-economical equilibrium in the area where it grows (Nouaim et al., 1991). The area of Essaouira produces between 1000 to 2000 tonnes of oil per year, corresponding very roughly to a local population of 60000-120000 trees, producing 142 million to 286 million fruits per year (Moussouris and Pierce, 2000).

Knowledge of genetic diversity within and among populations is particularly important for conservation management (Jian et al., 2006). Indeed, species that lack an appropriate amount of genetic diversity are generally unable to survive in a changing environment (Qian et al., 2001). The levels 
Table 1. Geographic coordinates of selected argan trees

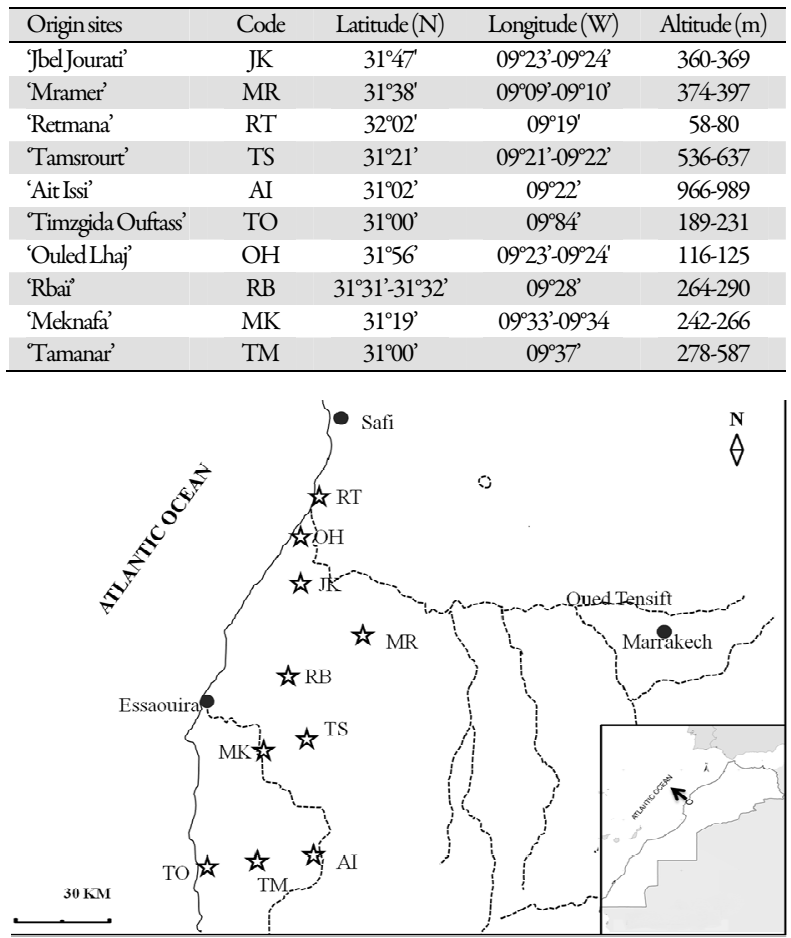

Fig. 1. The geographical distribution of the provenances of argan tree samples (see Table 1 for abbreviation)

of genetic variation between different populations and within the same population are the result of a dynamic interplay between several factors that include the gene flow, the selection effect, the inbreeding, the genetic drift and mutations (Hartl and Clark, 1994). Recently, molecular methods have provided accurate and reproducible tools to analyze the genetic variation of species, which is proven to be of great importance in planning efficient strategies for their conservation (Hamrick and Godt, 1996).

In Morocco, the argan ecosystem is subjected to a continuous degradation due to the anthropozoïc pressure, the dry climate, and the lack of natural regeneration. By consequence, the density of the argan tree forest suffered a regression from an average of 200 trees/ha to less than 30 trees/ha (Dupin, 1949; Nouaim $e t$ al., 1991). As a result, the conservation of the remaining genetic resources of argan forest became a priority, especially after the UNESCO declared the argan ecosystem as a Biosphere Reserve in 1998.

Most of the studies regarding the genetic variability of the argan tree used agromorphological approaches (Ferradous, 1995; Aameur and Ferradous, 2001; Benlahbil, 2003; Bani-Aameur, 2004; Ait Aabd et al., 2011). These studies strongly highlighted the existence of a high phenotypic diversity. However, morphological characteristics are usually not sufficient to give a clear picture of the existing genetic diversity. By contrast, the assessment of genetic diversity using DNA markers was proven to be more accurate and reliable.

The level of the genetic diversity of the argan trees in the wild remains poorly investigated. In fact, only few studies that focused on the genetic diversity of Argania spiniosa were published to date. The earliest investigations studied the isozymes markers and the DNA of chloroplast using PCR-RFLP (El Mousadik and Petit, 1996a; 1996b), followed by studying the Random Amplified Polymorphic DNA (RAPD) (Bani-Aameur and Benlahbil, 2004; Majourhat et al., 2008), and more recently studies on the Single Sequence Repeats (SSR) or microsatellites (Majourhat et al., 2008). Among these various molecular tools, the Inter-Simple Sequence Repeats (ISSR) using the PCR, remains the most reproducible, and gives a larger number of polymorphic fragments per primer. Indeed, it allows the identification of a very high number of loci, using only a few primers (Zietkiewicz et al., 1994). This technique also does not require prior knowledge of DNA sequence in order to design primers, straightforward to perform and cost effective compared to SSR and SNP. ISSR markers have been often successfully used to evaluate the genetic diversity of many species, such as Morus spp. (Kar et al., 2008), Barby fig (Opuntia ficus indica) (Ganopoulos et al., 2015), Quercus infectoria (Rahmani et al., 2015).

The aim of the present study is to examine the genetic diversity of naturel populations of Argania spinosa in the wild. The ultimate goal of this work is to establish a core collection representing the diversity that still remains conserved in the argan germplasm located in the region of Essaouira.

\section{Materials and Methods}

\section{The geographical area of the study}

The samples used in this study, were collected from 10 different selected area (provenances) in the region of Essaouira (Fig. 1) (i.e. 'JbelKourati', 'Mramer', 'Retmana,', 'Tamsrourt', 'Ait Issi', 'Timzgida Ouftass', 'Ouled Lhaj', 'Rbaii, 'Meknafa' and 'Tamanar'). These provenances represent different ecogeographical conditions in regards to the altitude and the proximity to the littoral. The geographical data for each sample (latitude, longitude, and altitude) shown in Table 1 were collected using the global positioning system (GPS).

\section{Biological materials}

Fresh leaves were collected from 20 individual trees per each provenance, and then stored at $-20{ }^{\circ} \mathrm{C}$. The trees were selected randomly and their locations were individually registered using the Global Positioning System (GPS).

\section{DNA extraction}

The genomic DNA was extracted from $40 \mathrm{mg}$ of grounded leaves, using a modified CTAB (Cethyltrimethyl Ammonium Bromide) procedure, initially described by Doyle and Doyle (1987). Briefly, $1 \mathrm{ml}$ of CTAB extraction buffer (1 M Tris-HCl $\mathrm{pH}$ 8.0, 1.36 M NaCl; 0.5 M EDTA pH 8.0, 0.5 M Poly-Vinyl Pyrrolidone (PVP) and CTAB 2\%) and $3 \mu \mathrm{l}$ of $\beta$ mercaptoéthanol were added to the leaves and the mixture was incubated at $65^{\circ} \mathrm{C}$ for $30 \mathrm{~min}$. Genomic DNA was extracted using chloroform: iso-amyl alcohol (24:1) and centrifugation at $10000 \mathrm{rpm}$ for $10 \mathrm{~min}$, at $4{ }^{\circ} \mathrm{C}$ was performed. The DNA was precipitated, from the supernatant, using isopropanol $(2 / 3$ volume of supernatant) and incubate overnight at $-20^{\circ} \mathrm{C}$. The precipitated DNA was collected by centrifugation at $14000 \mathrm{rpm}$ for $15 \mathrm{~min}$, and the pellet was washed successively in $76 \%$ ethanol containing $10 \mathrm{mM}$ ammonium acetate and in $75 \%$ ethanol. Finally, the dried pellets of DNA were dissolved in 100 
530

Table 2. List of ISSR primers used in this study

\begin{tabular}{|c|c|c|c|c|c|}
\hline Code & Sequence $\left(5^{\prime}-3^{\prime}\right)$ & $\mathrm{T}\left({ }^{\circ} \mathrm{C}\right)$ & {$\left[\mathrm{MgCl}_{2}\right] \mathrm{mM}$} & TNB & Size (bp) \\
\hline ISSR1-8 & CAGAGAGAGAGAGAGAGC & 56.0 & 2.0 & 21 & $200-1500$ \\
\hline ISSR3-8 & YGGAGAGAGAGAGAGAGAGY & 56.8 & 1.5 & 22 & $200-1000$ \\
\hline ISSR4-8 & YGACACACACACACACACYG & 53.5 & 2.0 & 28 & $200-2500$ \\
\hline ISSR5-8 & GTGTGTGTGTGTGTGTT & 55.3 & 1.5 & 33 & $200-2000$ \\
\hline ISSR6-8 & YTACACACACACACACACYT & 56.8 & 1.5 & 19 & $400-1500$ \\
\hline ISSR7/8 & AGCAGCAGCAGCAGCAGC & 60.5 & 2.0 & 6 & $400-1500$ \\
\hline ISSR8/8 & СТССТССТССТССТССТС & 59.8 & 2.0 & 7 & $200-900$ \\
\hline ISSR807 & GAGAGAGAGAGAGAGAC & 52.0 & 1.5 & 30 & $200-2000$ \\
\hline ISSR808 & СТСТСТСТСТСТСТСТА & 50.7 & 2.0 & 24 & $200-2000$ \\
\hline ISSR857 & ACACACACACACACACG & 52.0 & 2.0 & 26 & $200-2500$ \\
\hline
\end{tabular}

$\mathrm{T}^{\circ} \mathrm{C}$ : Temperature of annealing; TNB: Total number of band.

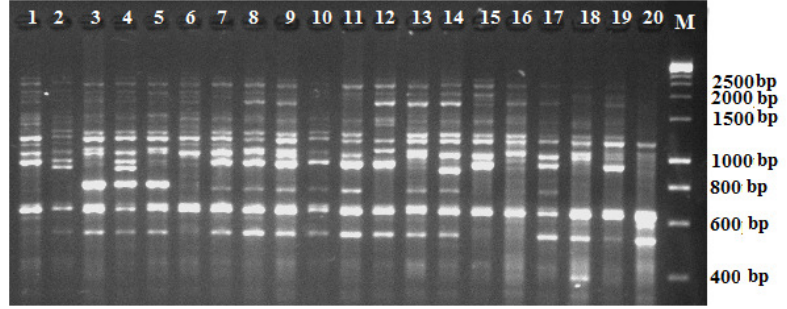

Fig. 2. DNA profile of ISSR amplification using the primer $4 / 8$ with samples from the 'Mramer' provenance $(\mathrm{M}=$ size marker, $\mathrm{bp}=$ base pair)

$\mu l$ of sterile ultrapure water. The quantity and the quality of DNA obtained were controlled by spectrophotometer and by electrophoresis in agarose gel $(0.8 \%)$ containing ethidium bromide. Aliquots of DNA samples were prepared at a concentration of $50 \mathrm{ng} / \mu \mathrm{l}$, and stored at $-20^{\circ} \mathrm{C}$ before use.

\section{ISSR PCR amplification}

In this study, ten ISSR primers that produced a clear, reproducible and relatively high polymorphism were used to estimate the genetic diversity of 200 samples (Table 2). These primers, previously described by Souto Alves et al. (2009), were successfully used to study a wide range of forest species (e.g., Apterosperma oblata (Su et al., 2008), Murraya koenigii (Verma and Rana, 2011).

The DNA amplification by PCR was performed in a $10 \mu \mathrm{l}$ reaction mixture containing $15 \mathrm{ng}$ of genomic DNA, Taq polymerase buffer $(1 \times), 0.2 \mathrm{mM}$ of dNTP, $0.2 \mathrm{mM}$ of primers (Eurofins) and $1 \mathrm{U}$ of Taq polymerase (Promega). The reaction mixture was supplemented with 1.5 to $2 \mathrm{mM}$ of $\mathrm{MgCl}_{2}$. The concentration of $\mathrm{MgCl}_{2}$ varied according to the nature of the primers (Table 2). The PCR was performed in a Thermal Cycler (Applied Biosystems 2720), using a program that start with an initial denaturation cycle at $94^{\circ} \mathrm{C}$ for $3 \mathrm{~min}$; followed by 30 cycles of $45 \mathrm{~s}$ denaturation at $94^{\circ} \mathrm{C}$, annealing at $50-60^{\circ} \mathrm{C}$ for 30 $s$ (depending on the type of primers) and 1 min extension at 72 ${ }^{\circ} \mathrm{C}$; and ending with final extension cycle at $72^{\circ} \mathrm{C}$, for $7 \mathrm{~min}$. The PCR products were visualized by separation for $2 \mathrm{~h}$ at a constant voltage $(90 \mathrm{~V})$, on agarose gel $(2 \%)$ (containing ethidium bromide).

\section{Statistical analysis}

The amplified fragments with the same mobility, on the agarose gel, according to their molecular weight (bp) were scored using a binary code [present (1) or absent (0)]. Each of these fragments represents a locus. The parameters related to the genetic diversity within and between different provenances [i.e. the percentage of polymorphic bands $(P P B)$, Nei's gene diversity $(b)$, Nei's genetic differentiation index among populations $\left(G_{s t}\right)$, allelic richness $(A)$ and gene flow $(\mathrm{Nm})]$ were calculated using POPGENE 1.32 (Yeh et al., 2000). An estimate of $N m$ among populations was calculated using the formula of $N m=0.5$ (1$\left.G_{s t}\right) / G_{s t}$ (McDermott and McDonald, 1993). The genetic distance matrix was employed to construct UPGMA tree (unweighted pair group method using arithmetic mean) using MEGA version 5 (Tamura et al., 2011). The molecular variance (AMOVA), using GenALEX version 6.5b3 (Peakall and Smouse, 2012) was used to estimate the distribution of the genetic variation between different provenances and within the same provenance. The correlation between the genetic and geographic distances was estimated using the Mantel test. A Bayesian analysis of ISSR population structure on the entire data set, using STRUCTURE 3.2 (Pritchard et al., 2000), was conducted to test for genetic admixture across provenances. STRUCTURE algorithm was run using the basic model with admixture and correlated allele frequencies, with the assumed number of genetic $\mathrm{K}$ clusters varying from 1 to 10 (the total number of provenances), ten replicate runs per $\mathrm{K}$ value(number of populations), and the burn-in period and Markov Chain Monte Carlo (MCMC) were set to 500,000 and 5000,000 iterations, respectively. To identify the number of $\mathrm{K}$ clusters explaining the observed genetic structure, statistical parameters defined by Evanno et al. (2005) based on the rate of change in the $\log$ probability of data between successive $\mathrm{K}$ values were used. Finally, it assembled a core collection that should represent the entire genetic diversity explored in the study using Powercore software (Kim et al., 2007).

\section{Results}

\section{Genetic diversity}

The results showed (i.e. Fig. 2) a total of 149 bands detected by using 10 screened primers across 200 individuals, from the 10 provenances studied. Among them, 148 (99.33\%) were polymorphic.

The 149 locus generated by 10 ISSR primers were sufficient to genetically characterize the studied provenances. To define the ISSR variation within the provenances, the POPGENE software was used to calculate five parameters that represent estimation for each locus, and the average represent the diversity in the loci. The analysis of the diversity within provenances (Table 3 ) showed that all the parameters followed the same direction $(A ; b ; N P B ; \% P)$. The 
Table 3. Genetic diversity within the argan provenances

\begin{tabular}{lcccc}
\hline Provenances & $A$ & $b$ & $N P B$ & $\% P$ \\
\hline 'Retmana' (RT) & 1.5302 & 0.2055 & 79 & 53.02 \\
\hline 'Ouled Lhaj' (OH) & 1.4832 & 0.1526 & 72 & 48.32 \\
\hline 'Jbel Kourati' (JK) & 1.6376 & 0.244 & 95 & 63.76 \\
\hline 'Mramer' (MR) & 1.6846 & 0.2332 & 102 & 68.46 \\
\hline 'Rbaï' (RB) & 1.6242 & 0.2032 & 93 & 62.42 \\
\hline 'Tamsrourt' (TS) & 1.557 & 0.209 & 83 & 62.42 \\
'Meknafa' (MK) & 1.6376 & 0.2053 & 95 & 63.76 \\
'Ait Issi' (AI) & 1.5772 & 0.2161 & 86 & 57.72 \\
'Tamanar' (TM) & 1.5638 & 0.1901 & 84 & 56.38 \\
\hline 'Timzgida Ouftass'(TO) & 1.6779 & 0.2398 & 101 & 67.79 \\
\hline Average & 1.59733 & 0.20988 & 89 & 60.405 \\
200 genotypes & 1.9933 & 0.3530 & 148 & 99.33 \\
\hline$A:$ Allelic richness; $h:$ Nei's genetic diversity; NPB: Number of polymorphic \\
bands; \%P: percentage of polymorphism.
\end{tabular}

Table 4. Analysis of the molecular variance (AMOVA) among the argan trees provenances

\begin{tabular}{ccccccc}
\hline $\begin{array}{c}\text { Source of } \\
\text { variation }\end{array}$ & DF & SS & MS & Est.var & $\%$ & $\begin{array}{c}p \text { - } \\
\text { value }\end{array}$ \\
\hline $\begin{array}{c}\text { Within } \\
\text { provenances } \\
\text { Among } \\
\text { provenances }\end{array}$ & 9 & 2285,010 & 253,890 & 11,939 & $44 \%$ & 0,010 \\
\hline
\end{tabular}

DF: degree of freedom; SS: sum of squares; MS: Mean Square; Est.var: estimation variance; $\%$ : Percentage variance.

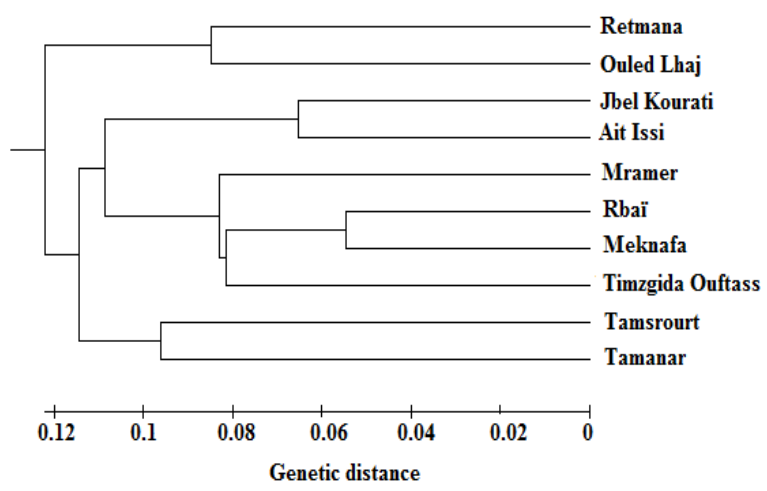

Fig. 3. UPGMA dendrogram based on Nei's genetic distances among the populations of the argan trees

highest and the lowest genetic diversity were observed in the 'Mramer' (MR) provenance (allelic richness, $A=1.6846$; Nei's genetic diversity, $h=0.2332 ; \%$ of polymorphic loci, $\% P=68.46)$ and 'Ouled Lhaj' $(\mathrm{OH}) \quad(A=1.4832 ; \quad h=0.1526 ; \% P=48.32)$, respectively. On the other hand, considering all provenances as a single group, a great genetic diversity is noted $(A=1.9933 ; b=0.353)$.

\section{Genetic differentiation and geneflow}

The AMOVA analysis showed that $56 \%$ of the total genetic variability resided between provenances (Table 4). This result was confirmed by the estimate of gene differentiation coefficient ( $G s t=0.4053$ ), which indicates that $40.53 \%$ of the total genetic variability exist between different groups of trees and $59.47 \%$ was within the groups. The level of gene flow $(\mathrm{Nm})$ was estimated to 0.7336 , indicating a limited rate of gene exchange among provenances.
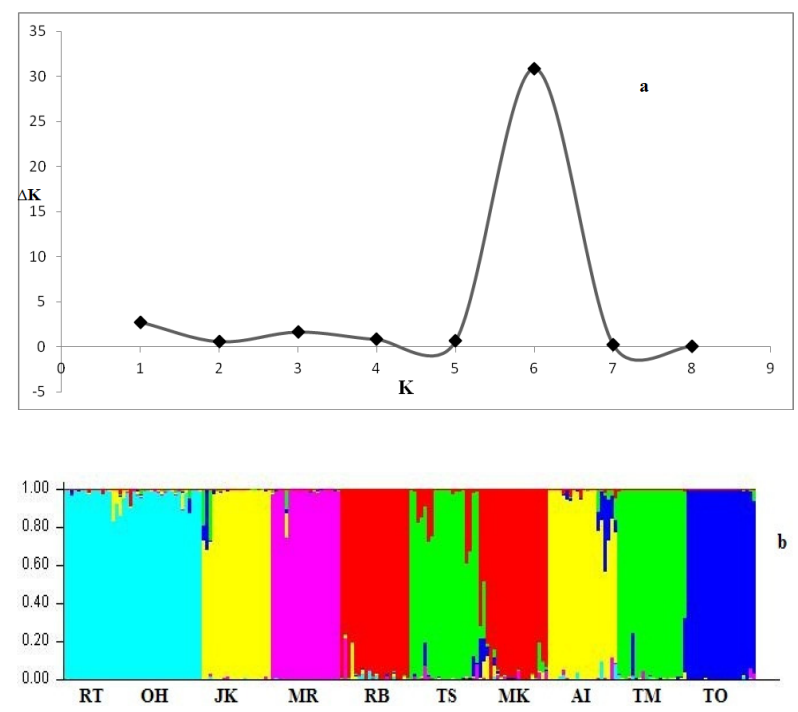

Fig. 4 . The genetic relationships among the 10 provenances of argan tree (200 individuals) estimated using STRUCTURE program based on ISSR data; (a) The $\Delta K$ (Evanno et al., 2005) was plotted against various values of $K$ suggesting $K=6$ as the most likely number of clusters, (b) assignation of individuals to the genetic clusters at $K=6$. The y-axis shows the likelihood distance and the $\mathrm{x}$-axis the accession and subgroup indicated by color. Each color represents one gene pool

\section{Genetic relationships}

The analysis with POPGENE indicated that the Nei's unbiased genetic distances is comprised between 0.1093 ('Rbail" vs 'Meknafa') and 0.2942 ('Retmana' vs 'Mramer'). Based on this, the UPGMA dendrogram showed that the 10 provenances formed six major distinct groups of clusters (Fig. 3). The 'Retmana' and 'Ouled Lhaj' formed a single group, as well as, the 'Jbel Kourati' and 'Ait Issi' provenances. The same was observed in the 'Rbai' and 'Meknafa' and the populations of 'Tamsrourt' with 'Tamanar', respectively. By contrast, the 'Mramer' and 'Timzgida Ouftass' formed two distinct groups of their own.

To measure the genetic divergence between these populations, it has been used the $G_{\text {st pairuise }}$ index (Palsbøll et al., 2007). The index values showed that all the populations studied were clearly differentiated. The highest genetic differentiation (0.3435) was particularly observed between 'Retmana' (RT) and 'Tamanar'(TM) (Table 5).

In the ISSR admixture analysis using STRUCTURE, the real $K$ value with the highest value of $\Delta K$ for the 200 individuals was $K=6$ (Fig. $4 \mathrm{a}$ ). The proportions of each provenance assigned into six clusters (cluster I and cluster II) (Fig. 4b) which result is in agreement with UPGMA dendrogram based on Nei's genetic identities. The Mantel's test (Mantel, 1967) results showed a positive but non-significant correlation between genetic structure and geographical distance $(r=0.181, P=0.120,999$ permutations).

\section{The construction of the core collection}

Core collection is a subset of accessions from the entire collection that capture, with minimum redundancy, most of the available genetic diversity of a crop, a wild species or a group of 
532

Table 5. The determination of the genetic differentiation between the different argan trees provenances using $G_{s t}$ pairuise index (see Table 1 for abbreviation

\begin{tabular}{|c|c|c|c|c|c|c|c|c|c|c|}
\hline Provenances & RT & $\mathrm{OH}$ & $\mathrm{JK}$ & MR & $\mathrm{RB}$ & TS & MK & $\mathrm{AI}$ & TM & TO \\
\hline RT & $* * * * *$ & & & & & & & & & \\
\hline $\mathrm{OH}$ & 0.2701 & $* * * * *$ & & & & & & & & \\
\hline JK & 0.2932 & 0.3012 & $* * * * *$ & & & & & & & \\
\hline MR & 0.3166 & 0.2874 & 0.2381 & $* * * * *$ & & & & & & \\
\hline $\mathrm{RB}$ & 0.2674 & 0.3217 & 0.2889 & 0.2392 & $* * * * *$ & & & & & \\
\hline TS & 0.3318 & 0.3343 & 0.2929 & 0.2456 & 0.296 & $* * * * *$ & & & & \\
\hline MK & 0.2979 & 0.3346 & 0.2547 & 0.1973 & 0.1757 & 0.2622 & $* * * * *$ & & & \\
\hline AI & 0.2912 & 0.3122 & 0.1778 & 0.2414 & 0.2846 & 0.2994 & 0.2584 & $* * * * *$ & & \\
\hline TM & 0.3435 & 0.3325 & 0.2721 & 0.2841 & 0.3187 & 0.2654 & 0.2905 & 0.302 & $* * * * *$ & \\
\hline TO & 0.2707 & 0.3175 & 0.2364 & 0.2093 & 0.2256 & 0.265 & 0.2052 & 0.2564 & 0.2424 & $* * * * *$ \\
\hline
\end{tabular}

Table 6. List of 13 trees out of 200 trees of entire collection included in core set formed by PowerCore

\begin{tabular}{|c|c|c|c|c|c|}
\hline Individuals & Region & Latitude (N) & Longitude (W) & Altitude $(\mathrm{m})$ & Number of loci \\
\hline RT19 & 'Retmana' & $32^{\circ} 02^{\prime} 28.5^{\prime \prime}$ & $9^{\circ} 19^{\prime} 17.1^{\prime \prime}$ & 77 & 100 \\
\hline TM19 & 'Tamanar' & $31^{\circ} 00^{\prime} 45.7^{\prime \prime}$ & $9^{\circ} 37^{\prime} 11.8^{\prime \prime}$ & 565 & 70 \\
\hline MK11 & 'Meknafa' & $31^{\circ} 19^{\prime} 16.5^{\prime \prime}$ & $9^{\circ} 34^{\prime} 02.8^{\prime \prime}$ & 261 & 85 \\
\hline TO4 & 'Timzgida Ouftass' & $31^{\circ} 00^{\prime} 19^{\prime \prime}$ & $9^{\circ} 48^{\prime} 11.3^{\prime \prime}$ & 213 & 74 \\
\hline RT5 & 'Retmana' & $32^{\circ} 02^{\prime} 18.7^{\prime \prime}$ & $9^{\circ} 19^{\prime} 25.6^{\prime \prime}$ & 70 & 86 \\
\hline AI19 & 'Ait Issi' & $31^{\circ} 02^{\prime} 03.9^{\prime \prime}$ & $09^{\circ} 22^{\prime} 34.3^{\prime \prime}$ & 973 & 85 \\
\hline MR12 & 'Mramer' & $31^{\circ} 38^{\prime} 34.4$ & $9^{\circ} 10^{\prime} 01.90^{\prime \prime}$ & 378 & 85 \\
\hline JK5 & 'Jbel Kourati' & $31^{\circ} 47^{\prime} 26.2^{\prime \prime}$ & $9^{\circ} 23^{\prime} 59.90^{\prime \prime}$ & 364 & 92 \\
\hline AI6 & 'Ait Issi' & $31^{\circ} 02^{\prime} 10.7^{\prime \prime}$ & $09^{\circ} 22^{\prime} 27.4^{\prime \prime}$ & 983 & 98 \\
\hline TS8 & 'Tamsrourt' & $31^{\circ} 21^{\prime} 34,2^{\prime \prime}$ & $9^{\circ} 22^{\prime} 52,9^{\prime \prime}$ & 550 & 83 \\
\hline TM17 & 'Tamanar' & $31^{\circ} 00^{\prime} 44,7^{\prime \prime}$ & $9^{\circ} 37^{\prime} 13,8^{\prime \prime}$ & 562 & 74 \\
\hline MR17 & 'Mramer' & $31^{\circ} 38^{\prime} 40,4^{\prime \prime}$ & $9^{\circ} 09^{\prime} 55,50^{\prime \prime}$ & 375 & 77 \\
\hline MR9 & 'Mramer' & $31^{\circ} 38^{\prime} 32,6$ & $9^{\circ} 10^{\prime} 06,40^{\prime \prime}$ & 386 & 76 \\
\hline
\end{tabular}

Table 7. Comparison of genetic diversity indices among the entire set and the core established

\begin{tabular}{lllll}
\hline Genotypes & $A$ & $b$ & $N P B$ & $\% P$ \\
\hline 200 genotypes & 1.993 & 0.3530 & 148 & 99.33 \\
13 genotypes of the core collection & 1.9396 & 0.3630 & 140 & 93.96 \\
\hline $\begin{array}{l}A: \text { Allelic richness; } b: \text { Nei's } \\
\text { polymorphic bands; } \% P \text { : percentage of polymorphism. }\end{array}$ & &
\end{tabular}

polymorphic bands; $\% P$ : percentage of polymorphism.

species (Brown, 1989a, b; Van Hintum et al., 2000, Belaj et al., 2012). Generally, information on geographic data, genetic data, or phenotypic data were used for grouping. To achieve this objective, an approach of maximization was adopted, using a heuristic algorithm implemented in the Power Core 1.0 software (Kim et al., 2007). This program allowed the selection of the most diverse genotypes covering all alleles existing in the original collection. The content of the core collection obtained using this software is shown in the Table 6. The results showed a Core collection representing existing genetic diversity that includes 13 genotypes from different regions selected by this program. This collection represents $6.5 \%$ of the total collection. The constructed core collection capture about $95 \%$ of the total diversity ( $A=1.9396 ; \quad b=0.3630 ; \% P=93.96)$. Indeed, the comparison of the genetic diversity indices between the genotypes included in the collection (13 genotypes) and the entire collection (200 genotypes) did not show any significant differences (Table 7).

\section{Discussion}

\section{Genetic diversity}

Genetic diversity is critical for the adaptation and the resistance to environmental changes and consequently for the long-term survival of a species. In this study, the high level of genetic diversity has reported in 'Mramer' provenance $A=1.6846 ; b=0.2332 ; \% P=68.46)$. By contrast, the argan tree from the provenance of 'Ouled Lhaj' $(\mathrm{OH})$, located in the North and closest to the ocean (less than $3 \mathrm{~km}$ ), were the less genetically diverse $(A=1.4832 ; \quad b=0.1526 ; \% P=48.32)$. However, if considering all the provenances that were studied as a single source, a high genetic diversity is noted $(A=1.9933, b=0.353)$ (table 3). In this work, the ISSR analysis using ten primers generated a higher polymorphism compared to other molecular markers such as isozymes (El Mousadik and Petit, 1996) and RAPD (Bani-Aameur and Benlahbil, 2004; Majourhat et al., 2008). In addition, the Argania spinosa showed a relatively higher mean of gene diversity using these ISSR markers compared to other species of trees (Zhao et al., 2006; JunMin et al., 2007; Sun et al., 2013; Vaishali et al., 2014, Rahmani et al., 2015). However, there was no significant difference between genetic diversity and altitude; high genetic diversity can be found in mountains and plains. Low and high genetic diversity between provenances could be attributed to many factors including, the geographical distribution combined with the level of isolation of the populations, the heavy deforestation and the extensive inhabitation.

\section{Genetic differentiation and geneflow}

The analysis of multi locus profiles has shown a very high level of differentiation inside the 10 provenances studied $\left(G_{s l}=0.4053 ; \quad\right.$ AMOVA $\left.=0, \quad 44 ; \quad N m=0.7336\right)$, which is consistent with our previous reports that focused on isoenzymes and chloroplast DNA of the argan tree $\left(G_{s t h}=0.25 ; G_{s t}=0.60\right)(\mathrm{El}$ Mousadik and Petit, 1996a; 1996b). Compared to other forest species, for instance the sessile oak that covers most of Europe 
and that is characterized by a low differentiation index $\left(G_{s}=0.026\right)$ (Kremer et al., 2002), it has been found that the argan tree is among the most genetically differentiated forest resources. This is consistent with reports in relation to other threatened or endemic species, like: Pinus sylvestris $\left(G_{s}=0.3965\right)$ (Hui-yu et al., 2005); Cupressus gigantea $\left(G_{s t}=0.36\right)$ (Xia et al., 2008); Machilus thunbergii $\left(G_{s t}=0.4118\right)$ (Liu et al., 2013) and Rheum palmatum and Rheum tanguticum $\left(G_{\text {stpalmatum }}=0.537 ; G_{s}\right.$ tanutuam $=497$ ) (Wang et al., 2012). The high genetic differentiation of the argan trees could be explained by several factors, including their geographical distribution, their breeding system (entomogame) and the genetic isolation of their populations. Indeed, the scattered distribution of species added to the topographic barriers can lead to difficulties in the dispersal of pollen and seeds, and consequently limit gene flow among populations ( $\mathrm{Lu}$ et al., 2008). Also, it was suggested that endemism and limited distributions of populations within a species favor a high genetic differentiation (Hamrick and Godt, 1990).

\section{Genetic relationships}

The knowledge of the genetic relationships among provenances of Argania spinosa is important information for the efficient use and ex situ conservation. According to the present data analysis, using UPGMA dendrogram, the argan trees included in this study could be divided into 6 distinct groups or clusters. Four of them were formed by trees from two different provenances, (i.e. 'Retmana' and 'Ouled Lhaj', 'Jbel Kourati' and 'Ait Issi', 'Rbaï and 'Meknafa', 'Tamsrourt' and 'Tamanar'). By contrast, the remaining two groups were formed by trees coming from a single provenance (i.e. 'Mramer' and 'Timzgida Ouftass'). Bayesian analysis showed that the germplasm collection of argan tree of Essaouira could be represented by six large groups, which is consistent with UPGMA cluster analysis. Further analysis like $G_{s t p a i n u s e}$ confirmed this genetic structure. However, there was no correlation between the genetic structures of these populations and their respective geographic distance $(\mathrm{r}=0.181, P=0.120,999$ permutations), indicating that geographic isolation was not the main factors inducing genetic difference.

The genetic structure of plant populations reflects the interactions of various evolutionary processes including the longterm evolutionary history of the species (e.g., shifts in distribution, habitat fragmentation, and population isolation), genetic drift, mutation, breeding system, and selection (Slatkin, 1987; Hamrick and Godt, 1996; Schaal et al., 1998). Therefore, the development of genetic structure within and between the populations of the argan tree in the region of Essaouira is probably strongly associated with the gene flow caused by the movement of pollen and seeds.

\section{Construction of nested core collections maximizing diversity}

The purpose of core collections is to facilitate the use of germplasm by providing a set of accessions displaying the genetic diversity available in the larger collection (Brown, 1989a), and this core collection facilitate experimental trials to assess germplasm under contrasting environmental conditions (El Bakkali et al., 2013). The current data analysis provides 13 individuals (6.5\% of the origin collection) defined by 10 ISSR markers (Table 6), which represent $100 \%$ of the genetic diversity of the entire collection (Table 7). The core collection established with heuristic analysis method could maintain specific alleles present in the entire collection (Zhang et al., 2011; Khaing et al,, 2013). In this sense, core collections exist for some fruit tree species (Volk et al., 2005; Escribano et al., 2008; Santesteban et al., 2009; El Bakkali et al., 2013; Miyamoto et al., 2014). In a comparative study, Belaj et al. (2012) used Mstrat and PowerCore to construct a core collection of Olea europaea L. their results showed the high efficiency of PowerCore to capture all alleles present in the source collection. This is consistent with the results obtained in multiple previous studies that have also suggested the efficiency of PowerCore (Agrama et al., 2009; Zhao et al., 2011; Kaga et al., 2012; Zhang et al., 2012; Khaing et al., 2013). Considering the present results, this collection might be an appropriate choice for applications involving the conservation of genetic resources of the argan trees. Field investigations must be taken as complementary criteria to ensure optimal management of the argan forest, in particular, criteria of phenotypic and agronomic aspect, but also of socioeconomic and environmental nature as this will help to utilize germplasm in breeding programmes more effectively.

\section{Conclusions}

In the current study, the ISSR analysis was a key tool to demonstrate a high level of genetic diversity between the argan trees from twelve different areas, which provides a potential resource of germplasm that might be used in the future conservation programs. Indeed, the determination of the genetic relationships between argan tree will further improve the efficiency of sampling and using of germplasm resources.

\section{Acknowledgments}

This work was supported by the Hassan II Academy of Science and Technology, Rabat, Morocco.

\section{References}

Agrama HA, Yan WG, Lee F, Fjellstrom R, Chen MH, Jia M, McClung A (2009). Genetic assessment of a mini-core subset developed from the USDA ricegene bank. CropScience 49(4):1336-1346.

Ait Aabd N, Elayadi F, Msanda F, El Mousadik A (2011). Evaluation of agromorphological variability of Argan tree under different environmental conditions in Morocco: Implication for selection. International Journal of Biodiversity and Conservation 3(3):73-82.

Bani Aameur F, Ferradous A (2001). Fruits and stone variability in three $\operatorname{argan}$ (Arganiaspinosa (L.)Skeels) populations. Forest Genetics 8:39-45.

Bani-Aameur F (2004). Morphological diversity of argan (Argania spinosa (L.Skeels)) Populationsin Morocco. Forest Genetics 11:311-316.

Bani-Aameur F, Benlahbil S (2004).Variation in RAPD markers of Argania spinosa trees and their progenies. Forest Genetics 11(3-4):337-342.

Belaj A, Dominguez-Garcia MC, Atienza SG, Urdíroz NM, De la Rosa R, SatovicZ, Martín A, Kilian A, Trujillo I, Valpuesta V,Del Río C (2012). Developing a core collection of olive (Olea europaea L) based on molecular markers (DArTs, SSRs, SNPs) and agronomic traits. Tree Genet Genomes 8(2):365-378.

Benlahbil S (2003). Natural and artificial pollination of the argan tree (Arganiaspinosa (L.) Skeels). Thesis presented for graduation graduate of 3rd cycle, Faculty of Science, University Ibn Zohr, Agadir, Morocco, p 157. 
534

Brown ADH (1989a). Core collections: A practical approach to genetic resources management. Genome 31:818-824.

Brown AHD (1989b). The case for core collections. In: Brown AHD, Frankel OH, Marshal DR (Eds). The use of plant genetic resources. University Cambridge Press, Cambridge,pp 136-156.

Doyle J, Doyle J (1987). A rapid DNA isolation procedure for small quantities of fresh leaftissue. Phytochem Bull 19:11-15.

Dupin P (1949). L'arganier survivant de la flore tertiaire, providence du Sud marocain, [Argan survivor of the tertiary flora, Providence of southern Morocco]. Elevages et Cultures 3:28 p.

El Bakkali A, Haouane H, Moukhli A, Costes E, Van Damme P, Khadari B (2013). Construction of core collections suitable for association mapping to optimize use of mediterranean olive (Olea europaea L.) genetic resources. PLoSOne 8(5), e61265.

El Mousadik A, Petit R (1996a). Chloroplast DNA phylogeography of the argan tree of Morocco. MolecularEcology 5(4):547-555.

El Mousadik A, Petit R (1996b). High level of genetic differentiation for allelic richness among populations of the argan tree [Arganiaspinosa $(\mathrm{L}$. Skeels] endemic to Morocco. Theoretical and Applied Genetics 92(7):832-839.

Escribano P, Viruelm A, Hormaza J (2008). Comparison of different methods to construct a core germplasm collection in woody perennial species with simple sequence repeat markers. A case study in cherimoya (Annona cherimola, Annonaceae), an underutilised subtropical fruit tree species. Annals of Applied Biology 153(1):25-32.

Evanno G, Regnaut S, Goudet J (2005). Detecting the number of clusters of individuals using the software STRUCTURE: A simulation study. Molecular Ecology 14(8):2611-2620.

Ferradous A (1995). Genetic diversity of some morphological characters of the fruit and seed of argan tree (Argania spinosa. (Skeels)). Thesis presented for graduation graduate of $3 \mathrm{rd}$ cycle. Ibn Zohr University, Faculty of Sciences, Agadir, Morocco, 189 p.

Frankel OH, Brown AHD (1984). Plant genetic resources today: a critical appraisal. In: Holden JHW, Williams JT (Eds). Crop Genetic Resources: Conservation and Evaluation, London. Allen \& Unwin Ltd, pp 249-257.

Freeland JR, Kirk H, Petersen SD (2011). Molecular Ecology, 2nd ed. Chichester: John Wiley \& Sons.

Ganopoulos I, Kalivas A, Kavroulakis N, Xanthopoulou A, Mastrogianni A, Koubouris G, Madesis P (2015). Genetic diversity of Barbary fig (Opuntia ficus-indica) collection in Greece with ISSR molecular markers. Plant Gene 2:29-33.

Hamrick JL, Godt MJW (1990). Allozyme diversity in plant species. In Brown AHD, Clegg MT, Kahler AL, Weir BS, editors. Plant population genetics, breeding, and genetic resources. Sunderland, MA: Sinauer Associates, pp 43-63.

Hamrick JL, Godt MJW (1996). Conservation genetics of endemic plant species. In: Avise JC, Hamrick JL (Eds). Conservation Genetics: Case Histories from Nature, New York: Oxford University Press, pp 281-304.

Hartl DL, Clark AG (1994). Principles of population genetics. Sinauer Associates, Sunderland, Massachusetts, USA.
Hui-yu L, Jing J, Gui-feng L, Xu-jun M, Jing-xiang D, Shi-jie L (2005). Genetic variation and division of Pinus sylvestris provenances by ISSR markers. Journal of Forestry Research 16 (3):216-218.

Jian SG, Zhong Y, Liu N, Gao ZZ, Wei Q, Xie ZH, Ren H (2006). Genetic variation in the endangered endemic species Cycas fairylakea (Cycadaceae) in China and implications for conservation. Biodiversity and Conservation 15:1681-1694.

Kaga A, Shimizu T, Watanabe S, Tsubokura Y, Katayose Y, Harada K, Vaughan D.A, Tomooka N (2012). Evaluation of soybean germplasm conserved in NIAS gene bank and development of mini core collections. Breeding Science 61(5):566-592.

Kar PK, Srivastava PP, Awasthi AK, Urs SR (2008). Genetic variability and association of ISSR markers with some biochemical traits in mulberry (Morus spp.) genetic resources available in India. Tree Genetics and Genomes 4(1):75-83.

Khaing AA, Moe KT, Chung JW, Baek HJ, Park YJ (2013). Genetic diversity and population structure of the selected core set in Amaranthus using SSR markers. Plant Breeding 132(2):165-173.

Kim KW, Chung HK, Cho GT, Ma KH, Chandrabalan D, Gwag JG, Kim TS, Cho EG, Park YJ (2007). PowerCore: a program applying the advanced $\mathrm{M}$ strategy with a heuristic search for establishing core sets. Bioinformatics 23(16):2155-2162.

Kremer A, Petit R, Ducousso A (2002). Biologie évolutive et diversité génétique des chênes sessile et pédonculé, [Evolutionary biology and genetic diversity of sessile and pedunculate oak trees]. Revue Forestière Française 54(2):111130.

Liu J, Sun H, Jiang J, Shao W, Luan Q (2013). Genetic diversity of natural populations of Machilus thunbergii, an endangered tree species in eastern China, determined with ISSR analysis. Genetics and Molecular Research 12(3):3689-3697.

Lu JY, Yang XM, Ma RJ (2008). Genetic diversity of clonal plant Polygonum viviparum based RAPD in eastern Qinghai-Tibet Plateau of China. Journal Northwest Normal University (Natural Science) 44:66-72.

Majourhat K, Jabbar Y, Araneda L, Zeinalabedini M, Hafidi A, Martínez-Gómez P (2007). Karyotype characterization of Argania spinosa (L.) Skeel (Sapotaceae). South African Journal of Botany 73(4):661-663.

Majourhat K, Jabbar Y, Hafidi A, Martínez GP (2008). Molecular characterization and genetic relationships among most common identified morphotypes of critically endangered rare Moroccan species Argania spinosa (Sapotaceae) using RAPD and SSR markers. Annals of Forest Science 65(8):805.

Mantel N (1967). The detection of disease clustering and a generalized regression approach. Cancer Research 27(2 Part 1):209-220.

McDermott JM, McDonald BA (1993). Gene flow in plant pathosystems. Annual Review of Phytopathology 31(1):353373. 
MHirit O, Benzyane M, Benchekroun F, El Yousfi SM, Bendaanoun M (1998). L'Arganier. Une espèce fruitière à usages multiples [The Argan tree. A fruit multipurpose species]. Pierre Mardaga, Sprimont, Belgique.

Miyamoto N, Ono M, Watanabe A (2014). Construction of a core collection and evaluation of genetic resources for Cryptomeria japonica (Japanese cedar). Journal of Forest Research 20(1):186-196.

Moussouris Y, Pierce A (2000). Biodiversity links to cultural identity in southwest Morocco: The situation, the problems and proposed solutions. Aridlands, 48. Retrieved December 30, 2008.

Msanda F, El Aboudi A, Peltier J (2005). Biodiversity and biogeography of Moroccan argan tree. Cahiers Agricultures $14(4): 357-364$.

Nei M (1978). Estimation of average heterozygosity and genetic distance from a small number of individuals. Genetics 89:583590.

Nouaïm R, Chaussod R, El Aboudi A, Schnabel C, Peltier JP (1991). L'arganier. Essai de synthèse des connaissances sur cet arbre. In: Groupe d'étude de l'arbre (Eds). Physiologie des arbres et arbustes en zones arides et semi arides. John Libbey Eurotext, Paris, pp 373-388.

Palsbøll PJ, Berube M, Allendorf FW (2007). Identification of management units using population genetic data. Trends in Ecology and Evolution 22(1):11-16.

Peakall R, Smouse PE (2012). GenAlEx 6.5: genetic analysis in Excel. Population genetic software for teaching and research an update. Bioinformatics 28(19):2537-2539.

Pritchard JK, Stephens M, Donnelly P (2000). Inference of population structure using multilocus genotype data. Genetics 155(2):945-959.

Qian W, Ge S, Hong DY (2001). Genetic variation within and among populations of a wild rice Oryza granulata from China detected by RAPD and ISSR markers. Theoretical and Applied Genetics 102:440-449.

Rahmani MS, Alikhani L, Shabanian N, Khadivi-Khub A (2015). Genetic differentiation in Quercus infectoria from northwest of Iran revealed by different nuclear markers. Tree Genetics and Genomes 11:800.

Santesteban LG, Miranda C, Royo JB (2009). Assessment of the genetic and phenotypic diversity maintained in apple core collections constructed by using either agro-morphologic or molecular marker data. Spanish Journal of Agricultural Research 7(3):572-584.

Schaal BA, Hayworth DA, Olsen KM, Rauscher JT, Smith WA (1998). Phylogeographic studies in plants: problems and prospects. Molecular Ecology 7:464-474.

Slatkin M (1987). Gene flow and the geographic structure of populations. Science 236:787-792.

Souto Alves T, Vanusa da Silva M, Alves de Almeida CM, Oliveira Jordão do Amaral D, Cordeiro dos Santos D, ... da Costa AF (2009). Genetic Diversity in Cactus Clones Using ISSR Markers. Acta Horticulturae 811:55-58.
Su YJ, Zan QJ, Wang T, Ying ZM, Ye HG (2008). High ISSR variation in 24 surviving individuals of Apterosperma oblate (Theaceae) endemic to China. Biochemical Systematics and Ecology 36:619-625.

Tamura K, Peterson D, Peterson N, Stecher G, Nei M, Kumar S (2011). MEGA5: molecular evolutionary genetics analysis using maximum likelihood, evolutionary distance, and maximum parsimony methods. Molecular Biology and Evolution 28(10):2731-2739.

Van Hintum TJL, Brown AHD, Spillane C, Hodgkin T (2000). Core collections of plant genetic resources. IPGRI Technical Bullletin No. 3. International Plant Genetic Resources Institute, Rome, Italy.

Verma S, Rana TS (2011). Genetic diversity within and among the wild populations of Murraya koenigii (L.) Spreng, as revealed by ISSR analysis. Biochemical Systematics and Ecology 39:139-144.

Volk GM, Richards CM, Reilley AA, Henk AD, Forsline PL, Aldwinkle HS (2005). Ex situ conservation of vegetatively propagated species: development of a seed-based core collection for Malus sieversii. Journal of the American Society for Horticultural Science 130(2): 203-210.

Wang XM, Yang R, Feng SF, Hou XQ, Zhang YQ, Li Y, Ren Y (2012). Genetic Variation in Rheum palmatum and Rheum tanguticum (Polygonaceae), Two Medicinally and Endemic Species in China Using ISSR Markers. PLoS One 7(12), e51667.

Xia T, Meng L, Mao K, Tian B, Miehe G, Liu J (2008). Genetic variation in the Qinghai-Tibetan plateau endemic and endangered conifer Cupressus gigantea, detected using RAPD and ISSR markers. Silvae Genetica 57(2):85.

Yeh FC, Yang R, Boyle TJ, Ye Z, Xiyan M (2000). POPGENE 32, Microsoft Windows-based Freeware for Population Genetic Analysis. Version 1.32 [CP/CD]. University of Alberta, Edmonton, Canada.

Zietkiewicz E, Rafalski A, Labuda D (1994). Genome fingerprinting by simple sequence repeat (SSR)-anchored polymerase chain reaction amplification. Genomics 20(2):176-183.

Zhang H, Zhang D, Wang M, Sun J, Qi Y, Li J, Wei X, Han L, Qiu Z, Tang S (2011). A core collection and mini core collection of Oryza sativa L. in China. Theoretical and Applied Genetics 122(1):49-61.

Zhang Y, Zhang X, Che Z, Wang L, Wei W, Li D (2012). Genetic diversity assessment of sesame core collection in China by phenotype and molecular markers and extraction of a mini-core collection. BMC Genetics 13(1):102.

Zhao WG, Chung JW, Lee GA, Ma KH, Kim HH, Kim KT, Chung IM, Lee JK, Kim NS, Kim SM (2011). Molecular genetic diversity and population structure of a selected core set in garlic and its relatives using novel SSR markers. Plant Breeding 130(1):46-54. 